\title{
The Institutionalisation of Teacher Ethics in Tanzania's Secondary Schools: A School Heads' Perspective
}

\author{
Daniel Sidney Fussy ${ }^{*}$
}

\begin{abstract}
This paper explores practices that school heads employ to institutionalise teacher ethics in Tanzania's secondary schools. It draws on qualitative data, generated through in-depth face-to-face interviews and document analyses. Secondary school heads, teachers and students from Iringa Municipality were involved in the study. The findings demonstrate that school heads employed several strategies to institutionalise teacher ethics, which include staff induction, allotment of weekly virtue practices, supervising and counselling individual teachers, assembling staff meetings and posting ethics related placards on staff room noticeboards. The study has shown that most of the practices lacked a profound impact on shaping teachers' professional conduct. The study adds knowledge to school leadership literature from Tanzania, particularly on the aspect of teacher ethics. Accordingly, the study recommends that school heads should institute mentoring programmes where by earlycareer teachers are attached to veteran teachers to regularly enhance their professional knowledge and behaviour. School heads should exemplify ethical conduct within and outside school premises by serving as role models for the teachers to facilitate the promotion of teacher ethics. Furthermore, education officers at the regional and district level should provide professional development programmes for school heads to further raise the awareness and confidence of school heads' professional obligations.
\end{abstract}

Keywords: teacher ethics, teacher professionalism, teacher misconduct, code of professional conduct, school heads

\footnotetext{
* Mkwawa University College of Education, Iringa, Tanzania E-mail: daniel.fussy@muce.ac.tz, danielfussy1@gmail.com
} 


\section{Introduction}

The Tanzanian Education Act No. 25 of 1978 amended in 1995 and 2002 has vested authority in school heads in the country to supervise and maintain teachers' conduct and discipline in secondary schools (Fussy, 2012; United Republic of Tanzania [URT], 2002). Despite such entitlement, there are ongoing cases of teacher misconduct in various secondary schools in Tanzania, which raises the question of whether school heads are effective in promoting teacher ethics. Studies have indicated that the chronic form of teacher misconduct is moonlighting, as teachers in the country engage in private activities (private tuitions, businesses, farm work) during official hours (Anangisye, 2011; Fussy, 2012; Ishumi, 2013; Mfaume \& Bilinga, 2016).Some teachers even sell sweets, snacks and ice-cream at school premises and often ask class monitors or other students to sell for them during break time.

In some schools, male teachers disregard the code of professional conduct requiring them to protect the pupils under their care by seducing female students to have sex with them. For example, a male teacher at Pomerini Secondary School in Iringa Region was sentenced to six years in prison for attempting to rape a 13-year-old female student (Edmund, 2011).Similarly, statistics from the Tanzanian Teachers' Service Department (TSD) for three consecutive years (2008/2009, 2009/2010 and 2010/2011) indicated that 472 teachers were dismissed yearly for professional misconduct, in which Iringa, Rukwa, Manyara and Pwaniregions topped the list of leading regions in teacher misconduct (URT, 2011).

The prevalent of teacher misconducts is a global concern. Literature increasingly indicates that teachers and educators in various developing and developed countries are implicated in different professional misconducts such as corruption, truancy, lateness, alcoholism, financial mismanagement, sexual immorality and drug abuse (Lauwerier \& Akkari, 2015; Mabagala, 2016; Mfaume \& Bilinga, 2016; Ndibalema, 2013). For example, using data derived from direct observations and unannounced visits in schools, Bold et al., (2017) found that only onethird of total instructional time was used in Kenya, Nigeria, Mozambique, Senegal, Tanzania, Togo and Uganda. The study highlighted that a significant waste of instructional time was largely a result of teachers unauthorised absence from the classroom even though they were at school. Bold et al., (2017) pointed the high rates of absenteeism to systemic teachers' governance, accountability and management issues.

The professional malpractices committed by teachers in turn take their toll on the students' attendance, learning and performance. They 
also jeopardise the efficiency of the education system by weakening the implementation of the planned educational interventions (Castro, Duthilleul \& Caillods, 2007; van Nuland \& Khandelwal, 2006; World Bank, 2018).Moreover, they culminate in the production of irresponsible, uncooperative, uncreative and corrupt citizens once learners graduate from schools (Anangisye, 2011;Hallak\& Poisson, 2007; Ishumi, 2013; Lauwerier \& Akkari, 2015).

Previous research on teacher ethics has based on finding the causes and prevalence of teacher misconducts and provide some suggestions in the form of recommendations on what educational leaders should do to curb misconducts (c.f.Anangisye, 2011; Anangisye \& Barret, 2005; Hallak \& Poisson, 2007; Mabagala, 2016; Mfaume \& Bilinga, 2016; Mulkeen, 2010; Ndibalema, 2013; Ng'oma \& Simatwa, 2013; Prinsloo, 2006). Knowledge on what educational leaders regularly do to foster teacher ethics is largely missing from this previous research. Additionally, most of these studies were conducted at primary level of education, and indeed, involved the highest education officers outside the school setting, such as School Inspectors/Quality Assurance Officers, Teachers'Service Department officers, Regional Education Officers, District Education Officers, and Ward Education Commissioners, excluding heads of school as the closest supervisors and colleagues who live and work with teachers at school level. Studying heads of school as a separate unit of analysis is crucial to learn the extent to which they manage to ensure teacher ethics are upheld within their institutions. Therefore, this study seeks to explore practices that school heads employ to institutionalise teacher ethics in Tanzanian secondary schools. In so doing, the study adds knowledge to school leadership literature from Tanzania, particularly on the aspect of teacher ethics. The study also provides practical recommendations to help raise efforts towards the promotion of teacher ethics in schools.

\section{Teacher Ethics and School Leadership}

Teachers, like any other professionals are obligated to observe ethics since their work involves close interactions with all kinds of people, particularly students within and outside the school setting. The observation and adherence to ethics by teachers necessitate the proper performance of teaching duties and eventually facilitate the attainment of educational goals (Anangisye, 2011; Lauwerier \& Akkari, 2015; Nwikina, 2013; World Bank, 2018). Siropolis (1997) defines ethics as "the rules or standards governing the conduct of a person or a profession". As for the teaching profession, teacher ethics refers to norms, values, standards and principles, such as responsibility, integrity, 
kindness, cooperation, justice, respect and honesty, officially accepted to govern teachers' conduct in their daily dispensation of duties to enhance commitment, efficiency and safeguarding of the reputation of the teaching profession (Dresscher, 2007; Nuland \& Khandelwal, 2006). Efforts to promote teacher ethics to respond to increasing teacher misconduct in various countries such as Tanzania have resulted in the establishment of a code of professional conduct for teachers. The teachers' code of professional conduct provides guidance on "how to act and how to make ethical decisions, through encouraging ethical awareness and reflection" (Banks, 2003). The code of professional conduct also helps teachers to maintain healthy relationships with their stakeholders including students, colleagues, employers and parents.

Managing teachers' professional conduct is not an easy task, however it is the responsibility of all education officers to ensure that teachers in schools are behaving professionally and perform their duties diligently. In their endeavour to fostering an ethical culture among teachers, school heads can employ different strategies. Day and Sammons (2016,) provide the following key dimensions of successful leadership, particularly for school heads or principals:

- Defining the vision, values and direction

- Improving conditions for teaching and learning

- Redesigning the organisation: aligning roles and responsibilities

- Enhancing teaching and learning

- Redesigning and enriching the curriculum

- Enhancing teacher quality (including succession planning)

- Building relationships inside the school community

- Building relationships outside the school community

- Placing an emphasis on common values

The implication is that for an ethical culture to prevail in schools, school heads should develop an internal staff organisation with clearly defined lines of duties, responsibilities, power and authority in a manner that best realised the purpose and direction of the school (Lauwerier \& Akkari, 2015; Ojo \& Olaniyan, 2008; World Bank, 2018). School heads should also demonstrate the importance of observing teacher ethics by their own behaviour. Studies have found that school heads who model ethical behaviours influence their teachers to behave ethically (Carnoy, 2006; Nwikina, 2013; World Bank, 2018). Moreover, school heads should monitor the behaviour of teachers by closely supervising teachers in the classroom, perusing their instructional materials and providing informative feedback. In Cuba and Bangladesh, for instance, school heads have established a specialised system of supervising teachers in the classroom to enhance teachers' instructional knowledge and determine 
which teaching/learning supplies and facilities are needed for the school and how those facilities can be effectively used (Carnoy, 2006; Dewanet al., 2004; Nwikina, 2013). Given the contextual variation of school leadership across the world, the analytical framework presented in this section guides the investigation of practices that school heads employ to promote teacher ethics in Tanzania's secondary schools, where there is a knowledge gap on the study of this nature.

\section{Methodology}

A qualitative research approach was employed to facilitate the data collection in this study, as the approach calls for studying a phenomenon in its natural and social settings by engaging the how and what questions on the socially-constructed reality (Cohen, Manion \& Morrison, 2007; Thomas, 2009). Since the qualitative research involves in-depth understanding of human behaviours and reasons that govern those behaviours, it facilitated the present study to establish practices that school heads employ to institutionalise teacher ethics and the reasons behind school heads' success or failure in this endeavour. The qualitative approach in this study was informed by a case study design. A case study is "an empirical inquiry that investigates a contemporary phenomenon in-depth and within its real-life context" (Yin, 2009, p. 18). In this study, the case study was deployed because the researcher intended to conduct an in-depth investigation on how school heads were engaged in promoting teacher ethics in their respective secondary schools. To that end, the data for this study were generated from Iringa Municipality of Iringa Region which is in Tanzania (East Africa). Iringa Region was selected because it topped the list of Tanzania's leading regions in teacher misconduct in a review conducted by the TSD between 2008/2009 and 2010/2011 (URT, 2011). Iringa Municipality was also selected because of its leading role in teacher misconduct among the four districts that form Iringa Region (URT, 2011).

Within Iringa Municipality, six secondary schools were involved in the study. These schools were purposively sampled based on public and private ownership as well as male and female school headship to increase diversity and rich data. Thus, three private and three public secondary schools were included. From the six secondary schools, a sample of 30 participants was drawn. The sample was purposively selected, and it was made up of six school heads (three males and three females), one from each school, 12 teachers, two from each school, and 12 students, two from each school. Teachers were selected based on gender and experience (short-served and long-served) and students were selected on the basis of their gender and leadership position of being head prefects. 
Adhering to ethical issues, the researcher sought the permission to conduct this study from relevant authorities. First, the researcher collected the research clearance letter from the University of Dar es Salaam, where the researcher is affiliated. This research clearance enabled the researcher to have access to Iringa Region Administrative Secretary (RAS). The named secretary, in turn, issued a permit to enable the researcher's access to Iringa Municipality District Administrative Secretary (DAS). The DAS too, issued a permit allowing the researcher to access relevant secondary schools in Iringa Municipality.

Within secondary schools, the researcher approached the school heads and explained the purpose of the study to them. Then the heads permitted the researcher to access teachers and students. On reaching teachers and students, individual informed consent from each was sought, regardless of school head's permission. Before data collection, participants were assured of confidentiality and anonymity. The researcher achieved that by keeping the collected data in a safe manner, such that no unauthorized person could access the information. Similarly, the researcher ensured anonymity through using pseudo names of schools and participants, particularly during reporting the findings and quoting participants' utterances verbatim. The six secondary schools under study were thus designated as Mbuluka, Kilama, Mtegeni, Litoke, Mbulisa and Lupala.

Data were collected using semi-structured face-to-face interviews and document analyses. With the consent of the study's participants, interviewees' responses were recorded by voice recorder prepared for such purpose, which were then transcribed verbatim by the researcher. Document analysis involved reviewing available documents to enable the researcher to get a sound grasp of what was documented on school heads' efforts towards promoting teacher ethics. Specifically, the documents reviewed included the directives and circulars from the Ministry of Education and Vocational Training (MoEVT) currently the Ministry of Education, Science and Technology, such as head teacher's guide book, teacher code of professional conduct and standing orders, that stipulate the roles and responsibilities of the school heads in managing teachers' conduct. The researcher also reviewed staff meeting records, minutes of school discipline committee (SDC) meetings, teacher attendance registers, teachers' lesson attendance forms, schemes of work, lesson plans and class journals. The review of these documents helped to create a clear picture of the school heads' practices in fostering teacher ethics.

Data sought through interviews and document analyses were subjected to thematic analysis. Thematic analysis allows for qualitative data to be analysed according to relevant themes (Braun \& Clarke, 2006; 
Creswell, 2009). Thematic analysis in this study involved six major stages: familiarisation with data, generating initial codes, searching for themes, reviewing themes, defining and naming themes and producing the report (Braun \& Clarke, 2006). All these stages were followed iteratively until themes were generated and the final report was written. Generally, the data analysis process resulted in the following major themes: staff induction, assembling staff meetings, allotment of weekly virtue practices, posting ethics related placards on staff room noticeboards and supervising and counselling individual teachers, as presented in the findings section.

\section{Findings}

\section{Staff Induction}

The findings indicate that school heads deployed induction programmes to familiarise teachers with the ethical conduct expected of them. These induction programmes which were largely offered to new teachers took the form of explaining to them about school rules and regulations, duties and responsibilities and the culture of the community around. In some schools, the new teachers were also provided with circulars and handouts during induction. School heads of Kilama and Lupala secondary schools provided the new teachers with the school's organisational chart, school rules and regulations, teacher's duties and responsibilities, vision and mission statements, school activity roster and the teachers' code of professional conduct. One participant who had eight months' experience added that: "Our school head provides relevant documents during orientation, and I have kept the documents in my personal file" (Teacher: Kilama Secondary School). After being permitted to peruse some teachers' personal files in that school, the researcher did, indeed find the listed documents.

Participants were also asked about the utility of the staff induction. They explained that the induction made them aware of their responsibilities, aided their understanding of the professional's dos and don'ts, and acquainted them with ethical principles of fairness, respect, diligence, responsibility and self-discipline. The question to raise thus far is how sustainable was the induction programme? Participants maintained that the induction was provided almost always to new teachers and ended the first week of their arrival. This suggests that further induction programmes or any other ethical related workshops/seminars were hardly conducted after the teacher has settled in the school. 


\section{Assembling Staff and other Meetings}

The assembling of staff meetings was another initiative used to inform and remind teachers of the importance of ethical conduct. The findings established two kinds of meetings conducted. The first meeting refers to compulsory meetings (usually two) which were convened at the beginning and at the end of each term. In such compulsory meetings, teachers were reminded to observe and keep good conduct by adhering to the proper dress code and showing the highest standard of punctuality, hard work and co-operation.The second meeting refers to emergency meetings. These meetings were convened when teachers were behaving unprofessionally. In such emergency meetings, the school heads reminded the teachers about their ethical obligations, depending on the type(s) of misconduct reported or uncovered.

The analysis of the documents from heads of school and those of the School Discipline Committees (SDCs) indicated that 22 emergency meetings for all six secondary schools under study were held in the year of fieldwork. One participant explained about one emergence meeting which their school head convened after a teacher organised a student trip to the national park without the consultation of the school management:

One teacher asked students to make contributions for a weekend tour to the Ruaha National Park. When the day of the trip came, the teacher tricked the students. Instead of sending them to the park, she sent them to a river located at a distant. The students went to that trip with the bus driver and the conductor only, as no any teacher, even the organizer, escorted the students. Oddly, all these were done without the blessing of the school administration. When that information leaked out, the following day, our head convened a meeting with all teachers. (Teacher: Mbulisa Secondary School).

Similarly, one school head elaborated on convening a meeting after being informed of a misconduct:

I remember, in the first term of this year, I called a meeting after receiving a case reported to me about two female students who fought over a male teacher. (School Head: Mtegeni Secondary School).

Participants also clarified that the meetings were usually taken by teachers as the place to air their grievances and express their resentments towards the management. Additionally, some teachers seized that opportunity to speak out against the evil deeds done by their fellow teachers and absolve themselves. In one school under study, teachers 
once gathered at a meeting called by their school head to listen to a case of two teachers who had failed to submit their terminal examinations to the academic office. The teachers said that they were preventing their exams from leaking out, as they had developed mistrust with the academic teacher responsible for handling all tests and examinations conducted in the school. These two teachers claimed that the academic teacher used to invite students to his office and stayed with these students for many hours. The academic teacher resented the allegations and explained that students visited in the academic teacher's office just to seek academic related support. This situation raises the concern of whether the initiatives used by school heads to promote teacher ethics were effective, as there was prevailing state of mistrust, irresponsibility and indiscipline among teachers.

\section{Posting Ethics Related Placards on Staff Room Notice-Boards}

The findings show that school heads posted copies of circulars on staff room notice-boards as one of their initiatives to institutionalise teacher ethics. Copies of posted circulars included; teachers' code of professional conduct, school regulations, responsibilities of the class master/mistress and those of the teacher on duty. Other documents included; the school's vision and mission statements, school activity roster, and the dress code adapted from the 2007 Public Service Circular number 3 on the recommended dress code for civil servants. The teachers' code of professional conduct document stipulates the rights and obligations for teachers. The teacher on duty guidelines stipulate that the teacher on duty is a captain and $\mathrm{s} / \mathrm{he}$ is supposed to know everything that happened during his/her week. The dress code document states explicitly what teachers should or should not wear. Jeans, shorts, caps, scribbled and pictured T-shirts and shirts were not allowed.

Despite the display of ethics related placards on staff room noticeboards, some teachers at Mtegeni, Mbuluka, and Mbulisa secondary schools were found wearing unauthorised clothes during fieldwork. Asked why they put on restricted clothes, these teachers reacted differently. One of them said:

Have you come to inspect what we are wearing or doing research [with a frown face]. (Teacher: Mtegeni Secondary School).

Another teacher reacted:

You know the classes I teach are on holiday, I have just come here to pass time. (Teacher: Mbuluka Secondary School). 
Another teacher explained:

I don't think it is a problem if I appear like this. The important thing is I'm committed to teaching students. (Teacher, Mbulisa Secondary School).

The posting of circulars on notice-boards intended to encourage ethical behaviour among teachers, however some teachers were reluctant to follow the message conveyed by the circulars.

\section{Allotment of Weekly Virtue Practices}

The study also found that the school head of Kilama Secondary School allotted each week for virtue practices involving teachers and students. This initiative involved the supply by the school head of a list of virtues to be observed for the whole academic year. The list consisted of many virtues, such as honesty, caring, diligence, love, commitment, cooperation, kindness, justice, humility and loyalty. The virtue practices worked like this; each week a chosen virtue, for instance 'caring' was assigned to an individual teacher and students of one class (e.g. form three). The teacher and the chosen class worked together for the whole week to observe that virtue. The teacher as a supervisor met with students and discussed with them the meaning of the chosen virtue, its importance and how to go about observing it. The virtue practices took different approaches depending on the requirements of the chosen virtue. If the virtue is responsibility, the students and their teacher may choose to clean up the school premises. They might slash grass, sweep the school grounds, dig new garbage pits, collect and burn wastes. Moreover, the class was required to demonstrate the virtue in the morning assembly for three to five minutes on Mondays and Wednesdays. On Fridays, the school head, or the deputy would award the exemplary students. Generally, weekly virtue practices were aimed at promoting ethics and love for manual work among teachers and students.

\section{Supervising and Counselling Individual Teachers}

The school heads counselled and supervised individual teachers in an attempt to institutionalise teacher ethics. The school heads played the role of supervision and counselling in two ways. They inspected folio records such as class journals, teacher attendance registers, teachers' logbook, lesson attendance forms, schemes of work, lesson plans and pupils' exercise books. The inspection of folio records was aimed at ensuring that the teachers fulfilled their job responsibilities effectively. 
Some teachers, however, explained that the inspection of folio documents was just intended to check if teachers have written something; feedback on the content were hardly provided. During a review of teachers' lesson plans, the researcher found that the major feedback teachers received was a signature of the school head or deputy school head, stamped and scribbled seen.

Moreover, the school heads also visited classrooms to observe the teachers' attendance and determine whether what was written in teachers' folio records was what the teachers taught in the classroom.

The following statement adds to this point:

The [school] head frequently visits classrooms to observe how teachers teach. Also,he has a tendency of going through our exercise books. (Head Prefect: Litoke Secondary School).

Another participant expressed a similar view:

I was once called by the head to his office after her visit in my class. She advised me on proper writing of a lesson plan. (Teacher: Kilama Secondary School).

The inspection of folio records and classroom visits were meant to ensure that the teachers did their job as required. It was also meant to gather information about teachers who were not committed to their work and identify ways of counselling them. Asked about the usefulness of the initiative, the school heads, teachers and students held the general view that school heads' supervision and counselling of individual teachers had helped improve teachers' classroom attendance.

\section{Discussion}

This study has found that school heads employ several strategies to institutionalise teacher ethics in Tanzania's secondary schools under review. These strategies include staff induction, assembling staff meetings, allotment of weekly virtue practices, posting ethics related placards on staff room notice-boards and supervising and counselling individual teachers, which are discussed in the following sub-sections.

The school heads primarily offered induction programmes to familiarise teachers with the ethical conduct expected of them. In some schools, the induction programmes were accompanied with the provision of documents necessary to keep teachers abreast of the professional requirements. The use of induction strategy was commended by the 
present study's participants as relevant to promote teacher ethics. The strategy is also supported by other studies which found it useful in acquainting recently employed teachers with the reality of the teaching profession and a new working environment (Fussy, 2012; Ishumi, 2013; Ngcongo, 1995).

Despite the induction strategy being relevant to improve teachers' ethical conduct, there is limitation to this strategy as it has been used in the present study and reported used in many other studies (c.f.Botha, 2011; Lauwerier\&Akkari, 2015; van Nuland\&Khandelwal, 2006). The present study has found that induction programme was provided to newly employed teachers and even then, it was just a one-day activity. Supporting this practice, Gold and Evans (1998, p. 55), for example, maintain that a great deal of attention during induction should be paid to newly appointed teachers to make meaning of the school and integrate them in aspects of professional practice such as punctuality, regular school attendance, effective teaching, learner discipline, teachers' code of conduct, collaborative working, respect and treating one another with dignity. This raises the question of how beneficial would the induction programme be if it is a one-off activity and provided mainly to newly employed teachers. Just because veteran teachers have accumulated years of experience in the teaching profession does not mean they should be deprived of the latest issues and developments about teaching. This orientation necessitates school heads and education leaders to think of a more inclusive strategy that will regularly update professional knowledge and requirements to both newly employed and experienced teachers.

Moreover, the present study has found that school heads used staff meetings as an avenue to inform and remind teachers of the importance of ethical conduct. These meetings were of two kinds: compulsory and emergency meetings. The use of staff meeting as an instrument for promoting teacher ethics is also supported by other educators. Mbiti (2007), for example, observes that staff meetings are important for the well-being of the school, as issues concerning the schools' academic status, staff welfare, staff's and students' discipline can be discussed during such gatherings. Similarly, Bakhda (2004) and Mosha (2011) contend that meetings between heads of school and their teachers are vital in promoting unity, co-operation, harmony, and achieving functional congruency within the schools.

The way staff meetings were used in the present study posed some challenges which limit their effectiveness in institutionalising teacher ethics. The analysis of staff meeting records revealed that the compulsory meetings conducted twice per term usually included many agendas. Again, the agendas were regularly changing depending on the prevailing pressing matter. As such, the agenda of teacher ethics was not 
included in every compulsory meeting, and if included, school heads tended to simply read what a teacher should or should not do. Likewise, the emergency meetings which were held when a case of teacher misconduct was reported also fell short of efficacy. As reported in the findings, the emergency meetings were taken by teachers as a place to express their grievances towards their fellow teachers and voice their resentments towards the management, shifting the focus of the meeting. Besides, convening a meeting after a misconduct has occurred is detrimental to the welfare of the school (Anangisye, 2011; Bold et al., 2017; Lauwerier \& Akkari, 2015; World Bank, 2018), as many cases of teacher misconduct can pass without the school heads or other teachers notice. In other words, the misconducts may have already brought negative effects at the time when they are heard and/or reported.

Furthermore, the study has established that school heads allotted a weekly virtual practice and posted copies of circulars on staff room notice-boards. The weekly virtue practices aimed at promoting ethics and love for manual work among teachers and students, which is also buttressed by Botha (2011) and Fussy (2012) who maintain that virtue practices are significant for ethical flourishing not only to individual teachers and students but also to other staff working in schools. Even then, this strategy was practised by only one school among the six schools under study. Additionally, some teachers were found wearing unofficial clothes at school premises although one posted circular carried a message of an authorised dress code. This suggests that the strategy of posting circulars has been less effective as some teachers did not see the logic behind adhering to a dress code relevant to the teaching profession.

Similarly, the present study has found that school heads played the role of supervision and counselling where they inspected teachers' folio records (class journals, attendance registers, logbooks, schemes of work, lesson plans) and visited classrooms to observe the teaching/learning process. Studies conducted in Cuba and Bangladesh reported similar findings whereby school heads employed classroom visits to ensure that teachers work responsibly, and students realise specified learning objectives (Carnoy, 2006; Dewanet al., 2004). Dissimilar findings were reported by Botha (2011) who found that principals in Eastern Cape schools - South Africa conducted class visits as a show case to the education officers when they visit their schools. They did not conduct classroom visit for improving teacher professionalism as teachers were negative about being supervised in the classroom and school heads were not confident enough to fulfil their supervisory duties.

Botha's (2011) observation also echoes what has transpired in the present study, where the inspection of folio records and classroom visits by heads of school intended to capture teachers' attendance but not to 
improve the effective preparation and delivery of the lesson. Such practice suggests that the promotion of teacher ethics in schools will remain an unattainable goal. World Bank (2018) emphasizes that ineffective school leadership means heads of school are not actively involved in supporting teachers solve professional problems, do not offer instructional advice and do not set goals that prioritize teaching and learning.

\section{Conclusion and Recommendations}

In a bid to improve teachers' professional conduct and eventually student learning outcomes, this qualitative-based study sought to explore practices that school heads employ to institutionalise teacher ethics in Tanzania's secondary schools. The study has established several practices include staff induction, assembling staff meetings, allotment of weekly virtue practices, posting ethics related placards on staff room notice-boards and supervising and counselling individual teachers. The study has shown that most of these practices lacked a profound impact on shaping teachers' professional conduct. This orientation can be one of the reasons justifies why teacher misconducts in Tanzania's secondary schools, particularly in the context of the study continue unabated. Accordingly, the study adds knowledge to school leadership literature from Tanzania, particularly on the aspect of teacher ethics.

Based on the study's conclusion, the following practical recommendations are advanced. First, school heads should institute mentoring programmes where by early-career teachers are attached to veteran teachers to leverage professional experience that will regularly enhance their professional knowledge and behaviour. Second, school heads should introduce a reward system for exemplary ethical teachers to motivate other teachers to behave professionally. Third, school heads should exemplify ethical conduct within and outside school premises by serving as role models for the teachers to facilitate the promotion of teacher ethics. Forth, education leaders/officers at the regional and district level such as Regional Education Officers, District Education Officers and School Inspectors/Quality Assurance Officers should institute professional development programmes for school heads to further raise the awareness and confidence of school heads' professional obligations. Finally, the institutionalisation of teacher ethics should not be left to school heads alone. Rather it should be concerted combined efforts of various actors, such as education officers, teachers, students and parents. 


\section{References}

Anangisye, W. A. L. (2011). Why are teachers motivated to behave unprofessionally? A qualitative-data-based-inquiry on educational stakeholders' experiences in Tanzania. A Journal of Contemporary Research, 8(1), 1-23.

Anangisye, W. A. L., \& Barret, A. M. (2005). Professional identity and misconduct: Perspective of Tanzanian teachers. Southern African Review of Education with Production, 11, 5-22.

Banks, S., (2003). From oath to rulebooks: A critical examination of code of ethics for the social professions. European Journal of Social Work, 6(2), 133-144.

Bennell, P., \& Akyeampong, K. (2007). Teacher motivation in subSaharan Africa and South Asia. London: Department for International Development.

Bhakhda, S. (2004). Management and evaluation of schools. Nairobi: Oxford University Press.

Bold, T., Filmer, D., Martin, G., Molina, E., Stacy, B., Rockmore, C., Svensson, J., \& Wane, W. (2017). What do teachers know and do? Does it matter? Evidence from primary schools in Africa. Policy Research Working Paper 7956. Washington, DC: World Bank.

Botha, R. J. (2011). The managerial role of the principal in promoting teacher professionalism in selected Eastern Cape schools. Africa Education Review, 8(3), 397-415.

Botha, R. J. (2011). The managerial role of the principal in promoting teacher professionalism in selected Eastern Cape schools. Africa Education Review, 8(3), 397-415.

Braun, V., \& Clarke, V. (2006). Using thematic analysis in psychology. Qualitative Research in Psychology, 3, 77-101.

Carnoy, M. (2006). Lessons from the past two decades: Investment choices for education and growth. Conference Paper Presented at Investment Choices for Education in Africa: DBSA/HSRC.

Castro, V. D., Duthilleul, Y., \&Caillods, F. (2007). Teacher absence in an HIV and AIDS context: Evidence from nine schools in Kavango 
and Caprivi (Namibia).Paris: International Institute for Educational Planning.

Cohen, L., Manion, L., \& Morrison, K. (2007). Research methods in education, $\left(6^{\text {th }}\right.$ ed). London: Routledge Falmer.

Creswell, J. W. (2009). Research design: Qualitative, quantitative and mixed methods approaches, ( $\left.3^{\text {rd }} \mathrm{ed}\right)$. Los Angeles: Sage.

Day C., \& Sammons, P. (2016). Successful school leadership. Berkshire: Education Development Trust.

Dewan, R. Z., Huque, A., Hoque, M., Muqtadir, A., Rahman, M. (2004). Better school management: The role of head teachers in Bangladesh. Paris: International Institute for Educational Planning.

Dresscher, E. (2007). Professional ethics in teaching and professional teachers' organizations. Retrieved May 22, 2011, from http://ebookbrowse.com

Edmund, J. (2011). Mwalimu jela miaka sita kwa kujaribu kumbaka mwanafunzi wake. Dar es Salaam: Majira.

Fussy, D. (2012). The effectiveness of school heads in institutionalising teacher ethics in Tanzania: The case of Iringa Municipality secondary schools. Unpublished M.A Dissertation. University of Dar es Salaam.

Gold, A., \& Evans, J. (1998). Reflecting on school management. London: Falmer Press.

Hallak, J., \& Poisson, M. (2007). Corrupt schools, corrupt universities: What can be done? Paris: International Institute for Educational Planning.

Ishumi, A. G. M. (2013). The teaching profession and teacher education: Trends and challenges in the twenty-first century. Africa Education Review, 10(S1), 89-116.

Lauwerier, T., \&Akkari, A. (2015). Teachers and the quality of basic education in sub-Saharan Africa. Paris: UNESCO Education Research and Foresight [ERF Working Papers Series, No. 11].

Mabagala, S. (2016). Prevalence of professional misconducts in Nzega, Tanzania public secondary schools. African Journal of Teacher Education, 5(1), 1-15. 
Mbiti, D. M. (2007). Foundations of school administration. Nairobi: Oxford University Press.

Mfaume, H., \& Bilinga, M. (2016). Prevalence of teachers' professional malpractices in Tanzanian public secondary schools: What ought to be done? Journal of Education and Training Studies, 5(2), 43-52.

Mosha, H, J. (2011). Towards managing educational institutions for excellence and perfection. Papers in Education and Development, 30, 179-205.

Mulkeen, A. (2010). Teachers in Anglophone Africa: Issues in teacher supply, training, and management. Washington, DC: World Bank.

Ndibalema, P. (2013). Stakeholder's attitudes towards the prevalence and problems associated to primary school teacher's professional misconduct in Tanzania: The case of Chamwino District. Journal of International Academic Research for Multidisciplinary (JIARM), $1(7), 31-54$.

Ng'oma, O. P., \& Simatwa, M. E. (2013). Forms, factors and preferred strategies in management of professional misconduct among public primary school teachers in Kenya. International Research Journal, $4(1), 44-63$.

Ngcongo, R. G. P. (1995). Educational leadership for schools: An African perspective. Pietermaritzburg: The Natal Witness Printing.

Nwikina, L. (2013). Fostering ethical behaviour and culture in Nigeria schools. International Journal of Learning \& Development, 3(6), 2636.

Ojo, B, L., \& Olaniyan, A. D. (2008). Leadership roles of school administrators and challenges ahead in post-primary institutions in Nigeria. European Journal of Scientific Research 24(2), 172-178.

Prinsloo, S. (2006). Sexual harassment and violence in South African schools. South African Journal of Education, 26(2), 305-318.

Siropolis, N. (1997). Small business management. New York: Houghton Mifflin Company.

Thomas, G. (2009). How to do your research project: A guide for students in education and applied social sciences. London: Sage. 
United Republic of Tanzania. (2002). Public act and regulations. Dar es Salaam: President's Office-Civil-Servant Commission.

United Republic of Tanzania. (2011). Teachers dismissed from service for various disciplinary offences in 2008/2009 and 2010/2011in the country.Dar es Salaam: Teachers' Service Department.

van Nuland, S., \& Khandelwal, B. P. (2006). Ethics in education: The role of teacher codes.Paris: International Institute for Educational Planning.

World Bank. (2018). World development report 2018: Learning to realize education's promise. Washington, DC: World Bank.

Yin, R. K. (2009). Case study research: Design and methods, $\left(4^{\text {th }}\right.$ ed.) Thousand Oaks: Sage.

\section{Citation of this Article:}

Fussy, D. S. (2018). The institutionalization of teacher ethics in Tanzania's secondary schools: A school heads' perspective. Pakistan Journal of Education, 35(2), 79-96.

Received on: November 10, 2017

Revised on: May

23,2018

Accepted on: July

02,2018 